\title{
An outbreak of compressive myelopathy due to pyogranulomatous reaction to the oily adjuvant of the foot-and-mouth disease vaccine - case report
}

[Surto de mielopatia compressiva associada à reação piogranulomatosa ao adjuvante oleoso da vacina contra Febre Aftosa em Minas Gerais - relato de caso ]

\author{
F.G. Melo ${ }^{1}$, M.E. Godoy ${ }^{2}$, E.J. Facury Filho ${ }^{3}$, A.U. Carvalho ${ }^{3}$, R.M. Meneses ${ }^{3}$, F. Pierezan ${ }^{3} *$ \\ ${ }^{1}$ Aluno de pós-graduação - Universidade Federal de Minas Gerais - Belo Horizonte, MG \\ ${ }^{2}$ Residente - Escola de Veterinária - Universidade Federal de Minas Gerais - Belo Horizonte, MG \\ ${ }^{3}$ Escola de Veterinária - Universidade Federal de Minas Gerais - Belo Horizonte, MG
}

\begin{abstract}
Cases of compressive myelopathy syndrome associated with post vaccinal pyogranulomas were diagnosed post mortem in three cows from a farm in Minas Gerais state, Brazil. These cows presented ataxia and bilateral paresis of the pelvic limbs, which evolved to paralysis, and sternal recumbence. On necropsy, locally extensive areas of the longissimus dorsi muscle were replaced by pyogranulomas supported by moderate amounts of fibrous connective tissue. On the cut surface, some nodules contained yellowish and viscous fluid (purulent exudate) or whitish fluid (interpreted as the oily adjuvant of a vaccine). In the spinal canal of the subjacent vertebrae, compressing the spinal cord, were pyogranulomas identical to those described in the skeletal muscle. Histologically, the pyogranulomas were composed of a central clear vacuole (consistent with the space left by the oil adjuvant droplets), surrounded by neutrophils and, more externally, by large numbers of epithelioid macrophages and fewer multinucleated giant cells. In the white matter of the spinal cord were numerous well-defined, clear vacuoles (Wallerian degeneration). The association of the clinical history and pathological findings allowed the diagnosis of compressive myelopathy associated with pyogranulomatous reaction to the oily adjuvant of the foot-andmouth disease vaccine, in this case, due to its inadequate application.
\end{abstract}

Keywords: vaccine reaction, myelopathy, medullary syndrome, neurologic diseases.

\section{RESUMO}

São descritos casos de síndrome de compressão medular, associada a granulomas pós-vacinais, em bovinos Nelore, provenientes de uma propriedade em Minas Gerais. Esses bovinos apresentavam ataxia e paresia bilateral dos membros pélvicos, que evoluiu para paralisia e decúbito esternal. Na necropsia, áreas focalmente extensas da musculatura na região torácica dorsal (músculo longissimus dorsi) eram substituídas por numerosos piogranulomas, separados por tecido brancacento e firme (tecido conjuntivo fibroso). Ao corte, alguns nódulos continham material amarelado e viscoso (exsudato purulento) ou material esbranquiçado e fluido (sugestivo de adjuvante de vacina). No canal medular das vértebras subjacentes, havia granulomas idênticos aos observados no tecido muscular. Histologicamente, os piogranulomas continham, no centro, vacúolo, bem delimitado e arredondado (consistente com o espaço deixado pela gotícula de lipídio do adjuvante), circundado por variável quantidade de neutrófilos degenerados e íntegros e, mais externamente, por numerosos macrófagos epitelioides e algumas células gigantes multinucleadas. Nas áreas da medula espinhal, circundadas pelos granulomas, numerosos vacúolos, bem definidos, eram observados na substância branca (degeneração walleriana). A associação do histórico clínico e de achados patológicos permitiu o diagnóstico de mielopatia compressiva associada à reação granulomatosa ao adjuvante oleoso da vacina contra febre aftosa, no caso, induzida pela aplicação inadequada da vacina.

Palavra-chave: reação vacinal, mielopatia, sindrome medular, doença neurológica

Recebido em 22 de fevereiro de 2018

Aceito em 27 de dezembro de 2018

* Autor para correspondência (corresponding author)

E-mail: fpierezan@gmail.com 


\section{INTRODUCTION}

Compressive myelopathies are uncommon in ruminants and are associated with spaceoccupying lesions in the spinal canal, such as abscesses, granulomas, traumas, malformations and neoplasms (Sherman and Ames, 1986; McAllister et al., 1995, O'Toole et al., 1995; Borges et al., 2003; Ubiali et al., 2011; Panziera et al., 2014; Panziera et al., 2016). Traumas and vertebral abscesses are more frequent in beef cattle, while neoplasms, mainly lymphomas, are seen, more commonly, in adult dairy cows (Sherman and Ames, 1986; Jacobs et al., 2002). Granulomas within the spinal canal have been described in association to post vaccinal reactions to the oily adjuvant of vaccines in the USA and Brazil (McAllister et al., 1995; O'Toole et al., 1995; O'Toole et al., 2005; Ubiali et al., 2011; Marques et al., 2012; Panziera et al., 2016). These cases occur, more frequently, as isolated cases in the herds, and are usually related to the inadequate application of the vaccine in the thoracic or lumbar region. Outbreaks are rarely described. Clinical signs of compressive myelopathies include ataxia, paresis and paralysis of the thoracic or pelvic limbs and progressive loss of muscular tonus (McAllister et al. 1995; O'Toole et al., 2005; Ubiali et al., 2011; Marques et al., 2012; Panziera et al., 2016). Due to the clinical presentation, these syndromes are confused with other important neurological diseases, such as rabies and botulism. The goal of this report is to describe the epidemiological, clinical and pathological aspects of an outbreak of compressive myelopathy due to pyogranulomatous reaction to the oily adjuvant of the foot-and-mouth disease vaccine, in a herd, in Minas Gerais state, Brazil.

\section{CASE REPORT}

Three sick Nelore cows (one 8-month-old and two 3-year-old) were submitted to the Veterinary Hospital of the Universidade Federal de Minas Gerais (UFMG), as well as samples of the spinal cord of a cow (Nelore, 3-year-old), collected during a field necropsy. These four cows were from a farm in Minas Gerais state, with a herd of 3,000 cattle, where, in the past 3 years (2013-
2016), 35 cows died after presenting similar clinical signs characterized by ataxia, paresis and paralysis of the thoracic or pelvic limbs, emaciation, and sternal recumbency. The duration of these signs varied from 5 to 60 days. According to the owner, among these 35 cows, only two recovered without any treatment, while all others were submitted to euthanasia or died due to inanition. The herd was vaccinated against foot-and-mouth disease (FMD) twice a year.

On clinical examination, all cows presented poor body condition and normal consciousness. The cows presented moderate locomotor signs characterized by paresis of the pelvic limbs. Superficial and profound sensitivity were reduced in the pelvic limbs and tail. After seven days, two cows were euthanatized due to the progression of the clinical sigs to severe ataxia, inability to stand, and emaciation.

On necropsy, locally extensive areas of the skeletal muscle of the thoracic region (longissimus dorsi muscle - overlying the vertebras T3-T7 [bov1] and T12-13 [bov2]), were replaced by numerous yellow and firm coalescent nodules (pyogranulomas) with 0.3$0.8 \mathrm{~mm}$ in diameter, surrounded by moderate amounts of a white and firm tissue (fibrous connective tissue). On the cut surface, some nodules contained yellowish and viscous fluid (purulent exudate) or whitish and viscous fluid (interpreted as the oily adjuvant of the FMD vaccine). In the spinal canal of the subjacent vertebrae, extending from the intervertebral foramen to the epidural space and dura mater, and compressing the spinal cord, there were pyogranulomas identical to those described in the skeletal muscle (Figure 1). The remaining dura mater was thickened and firm (fibrosis). Fragments of the spinal cord and meninges, brain, skeletal muscle and other organs were fixed in $10 \%$ formalin and processed for paraffin embedding. After histological processing, $5 \mu \mathrm{m}-$ thick sections were stained with hematoxylin and eosin (HE). Histological sections of the spinal cord and meninges were also submitted to ZiehlNeelsen. Periodic acid-Schiff (PAS), Grocott methanamine silver (GMS) and, Gram staining. 


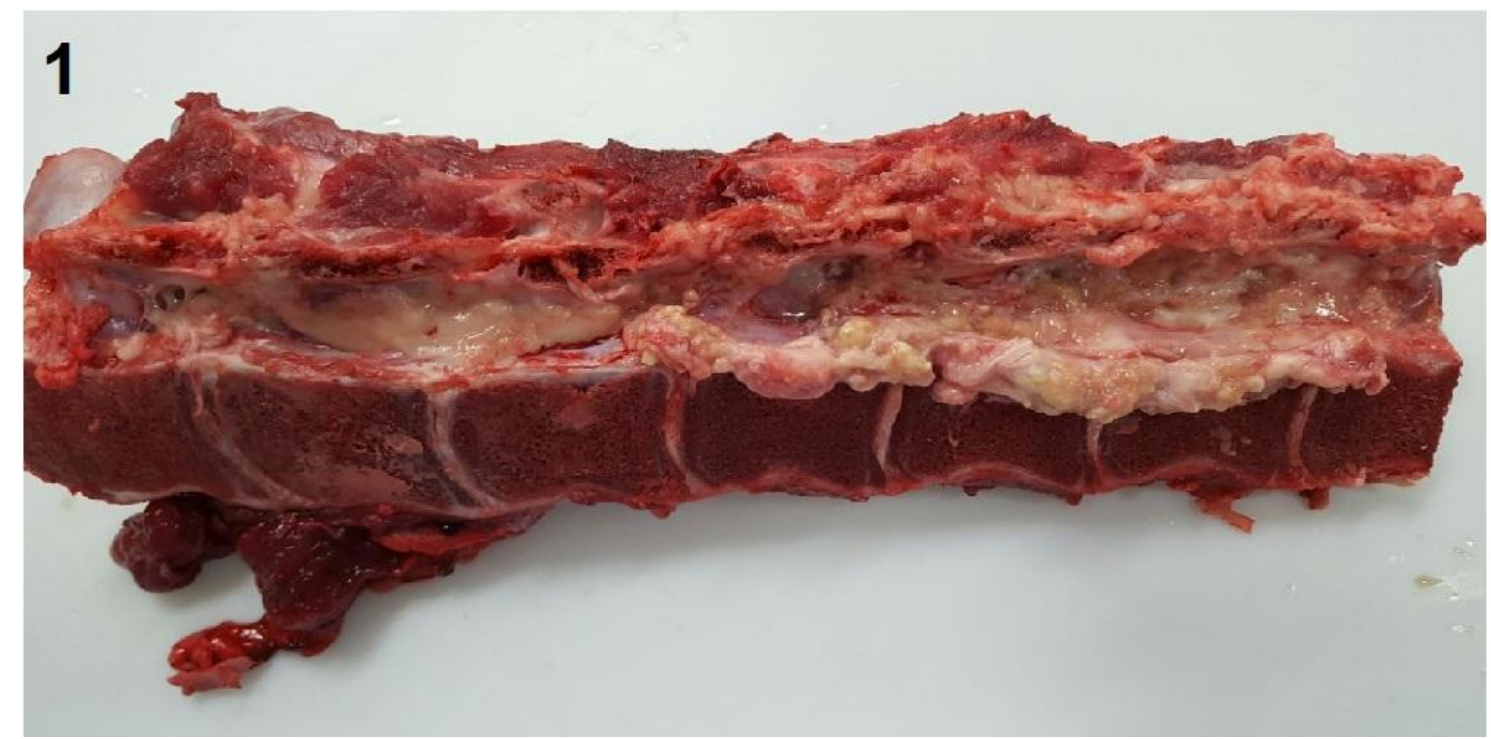

Figure 1. Within the spinal canal, the epidural space and dura mater were thickened due to multiple 0.3$0.8 \mathrm{~mm}$ diameter, yellow and firm coalescent nodules (pyogranulomas) surrounded by moderate amounts of fibrous tissue.

Histologically, in the skeletal muscle and spinal canal, the muscle fibers, epidural space and dura mater were expanded, and partially to completely effaced by extensive areas of pyogranulomatous inflammation with proliferation of fibrous connective tissue. The pyogranulomas were composed by a central clear vacuole (ranging from 30 to $300 \mu \mathrm{m}$ ) (interpreted as the space left by the oil adjuvant droplets), surrounded by variable numbers of degenerated and viable neutrophils, with occasional aggregates of necrotic material and mineralization, and, more externally, by large numbers of epithelioid macrophages and fewer multinucleated giant cells, lymphocytes and plasma cells. Single or multiple, $10-30 \mu \mathrm{m}$, clear vacuoles were observed within the cytoplasm of multinucleated giant cells (Figure 2 and 3). These structures were further surrounded by a thick layer of dense fibrous connective tissue admixed with blood vessels. Extensive areas of the dura mater were replaced by fibrous connective tissue infiltrated by low to moderate numbers of lymphocytes, plasma cells, and macrophages. Pyogranulomas and fibrous tissues invaded and compressed the adjacent nerve fibers. In the white matter, of the affected sections of the spinal cord, there were numerous well-defined, large and clear vacuoles (dilated periaxonal spaces) containing either swollen axons (spheroids) or foamy macrophages (digestion chambers) (Figure 4). No infectious agents were observed in special stains. No lesion was observed in the brain, as well in the other submitted tissues.

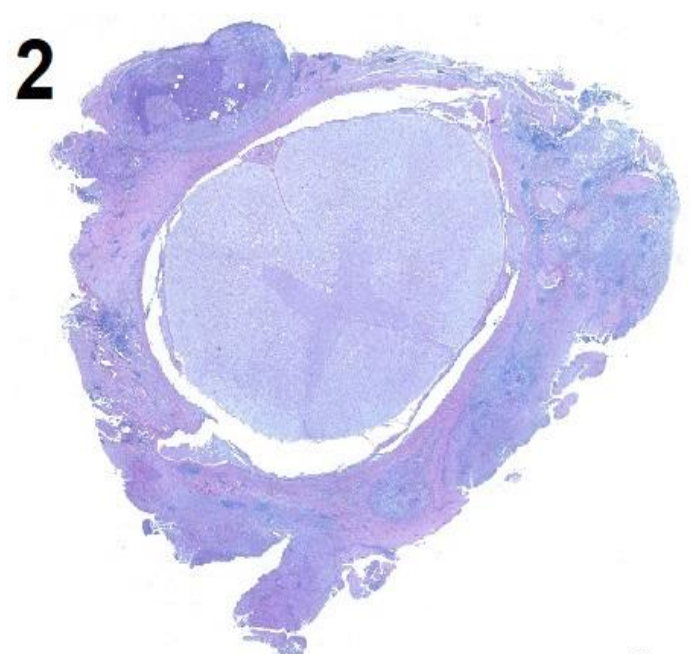

Figure 2. Sub gross examination of the spinal cord showing extensive areas of fibrosis and scattered pyogranulomas extending outwards from the dura. HE. 


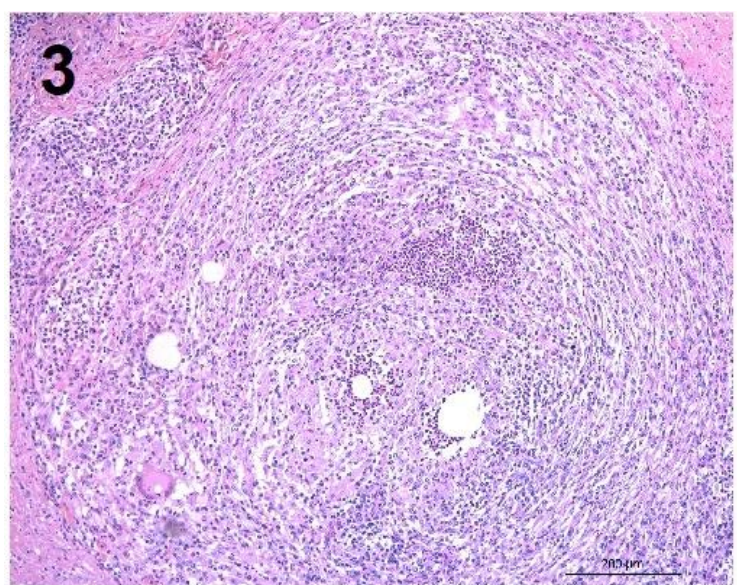

Figure 3. Pyogranulomas in the dura mater, composed by central clear vacuoles (interpreted as the space left by the oil adjuvant droplets), surrounded by variable numbers of degenerated and viable neutrophils, and, more externally, by large numbers of epithelioid macrophages and fewer multinucleated giant cells, lymphocytes and plasma cells. HE.

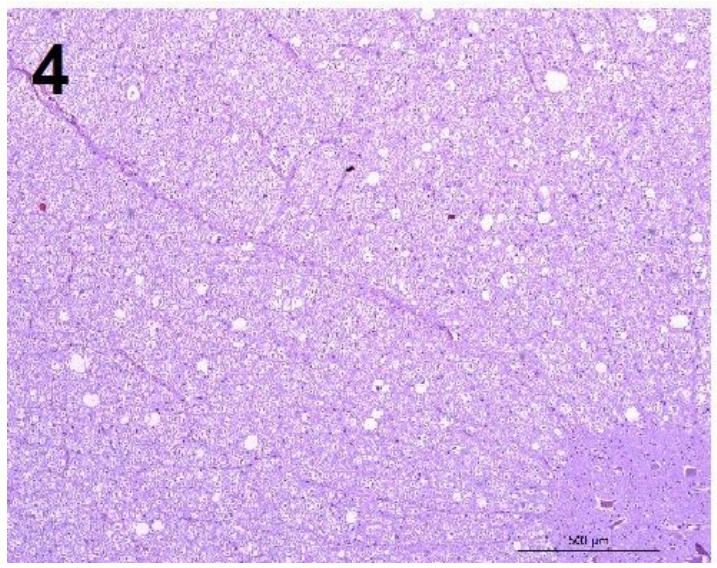

Figure 4. The white matter of the affected sections of the spinal cord, with numerous welldefined, large and clear vacuoles (dilated periaxonal spaces). HE.

\section{DISCUSSION}

History, clinical signs and gross and histopathological findings, in these four cows, were compatible with compressive myelopathy due to pyogranulomatous reaction to the oily adjuvant of a vaccine. The history of previous application of the FMD vaccine in the thoracic region (site of the muscular pyogranulomas) indicated its involvement with these lesions. Even though some cases of this syndrome have been reported in the literature, this report describes several cases of the condition, in a herd where a medullary syndrome had been the reason for the euthanasia or death of several cows in the past three years. The mortality index of $1.16 \%$ was similar to the index observed in other reports of this condition (McAllister et al., 1995; O'Toole et al., 1995; O'Toole et al., 2005; Ubiali et al., 2011; Marques et al., 2012; Panziera et al., 2016). Interestingly, these index of morbidity and mortality were observed only in herds were the application of the vaccine is reported to be in the thoracic or lumbar region.

In this farm, other vaccines were used in the past three years, including the ones against rabies and black leg. Nevertheless, only the FMD vaccine contains an oily adjuvant able to induce pyogranulomatous lesions. The adjuvant used in the FMD vaccine is as a water-in-oil emulsion (Ubiali et al., 2011; Marques et al., 2012; Panziera et al., 2016). Granulomas are expected structures when oily adjuvants are used and have an important role in the maintenance of the humoral activity of the vaccine. Contamination of needles and syringes are factors that predispose exacerbated reaction. The water-in-oil adjuvant used in a Clostridium perfringens type $\mathrm{C}-E$. coli bacterin-toxoid vaccine and in a Rotavirus and Coronavirus vaccine, was also able to induce muscular lesions, such pyogranulomas, fibrosis, mineralization and necrosis (McAllister et al., 1995, O’Toole et al., 2005). Pyogranulomatous inflammation in the skeletal muscle and epidural space was also reported in cows after the application of an Escherichia coli/Campylobacter bacterin in an oil adjuvant (McAllister et al., 1995, O’Toole et al. 1995).

Thus, oily adjuvants are recognized as causes of pyogranulomatous reactions, as observed in our cases.

An important factor for the development of the medullary lesions was the inappropriate application of the vaccine in the muscle of a paravertebral area of the thoracic region. According to the orientation from the manufacturers of the vaccine and from the guidelines of the National Program for the Eradication of foot-and-mouth disease (Brasil, 2017), this vaccine must be applied subcutaneously or intramuscularly, in the lateral cervical region. Even when applied in the 
recommended location, subcutaneous and muscular lesions are frequently observed in the application sites. These lesions are either granulomas or abscesses and are an important source of economic losses due to the cost to trimming the lesion in slaughterhouses (Leal et al., 2014; Lima et al., 2014). According to the owner of these cows, the application of the vaccine in the thoracic region was performed to avoid evident subcutaneous and muscular lesions in the cervical area and to facilitate the procedure when it was performed in a basic cattle handling system with straight race. This method of application was based on the empirical knowledge of the owner and there is no scientific evidence showing that some application sites are related to minor reactions.

The thoracolumbar location of the lesions and paresis restrict to the pelvic limbs, associated to the absence of consciousness disturbances, allowed the characterization of the cases as a medullary syndrome. These signs of sensitivity and locomotor disturbances indicated lesions of axonal degeneration and demyelination, as well as lesions in the dorsal and ventral ganglia. These lesions were identical to those observed in previous reports of compressive myelopathies due to reaction to the oily adjuvant of a vaccine (McAllister et al. 1995; Ubiali et al., 2011; Marques et al., 2012; Panziera et al., 2016).

Macroscopic lesions were characterized by pyogranulomatous reaction. Interestingly, some of these structures contained whitish and viscous material similar to the vaccine fluid. The presence of this material within the lesions is not commonly described in reports of this condition (Ubiali et al., 2011; Marques et al., 2012; Panziera et al., 2016). Macroscopically, these pyogranulomas are similar to granulomas observed in cases of meningitis due to Mycobacterius bovis infection and the identification of the agent by Ziehl-Neelsen is definitive for the differential diagnosis. The presence of typical intralesional vacuoles (interpreted as the space left by the oily adjuvant of the vaccine, removed during the processing for the histopathological analysis) and the absence of infectious organisms on special stains (GMS, PAS, Gram and Ziehl-Neelsen acid-fast) corroborate the association of the lesions to the adjuvant of a vaccine.

Even though some studies hypothesize the insertion of the needle in the intervertebral foramen as the cause of the extension of the lesions to the spinal canal, histologic evidences suggest the movement of the adjuvant during the application or progressively, due to the rupture of the granulomas, as mechanisms to be considered. This later hypothesis is corroborated by the observation of ruptured granulomas, presence of degenerated neutrophils within the granulomas and occasional free vacuoles among the granulomas. Migration through the tissues is a well-known property of water-in-oil adjuvants (McAllister et al., 1995, O'Toole et al., 1995, Panziera et al., 2016).

Vaccination against FMD is one of most important policies for animal health in the beef cattle industry in Brazil. FMD is a highly contagious viral disease affecting cloven-hoofed animals. It has great potential for causing severe economic loss, due its importance for commercial trade, and the requirement for total elimination of the affected herds. Brazil has had no outbreaks of FMD since 2005, when outbreaks in two states led to the sacrifice of 39,845 cattle. Currently, the country has 4 zones (corresponding for $76.1 \%$ of the national territory) certified as free of the disease with use of vaccination and 1 zone (corresponding for $1.1 \%$ of the national territory) as free of the disease without using vaccination (Brasil, 2017). Thus, even though the vaccination against FMD occurs in the majority of the national territory, a few cases of compressive myelopathy are observed, despite the common observation of other reactions such as subcutaneous abscesses and granulomas.

\section{CONCLUSION}

In conclusion, cases of compressive myelopathy observed in this herd in Minas Gerais state, Brazil, were associated to the pyogranulomatous reaction to the adjuvant after the inadequate use of the FMD vaccine and, thus, this condition must be included as a differential diagnosis for medullary syndromes in ruminants. 


\section{REFERENCES}

BORGES, A.S.; SILVA, D.P.G.; GONÇALVES, R.C. et al. Fraturas vertebrais em grandes animais: estudo retrospectivo de 39 casos (19872002). Arq. Bras. Med. Vet. Zootec., v.2, p.127132,2003

BRASIL. Ministério da Agricultura. Programa Nacional de Erradicação da Febre Aftosa. Brasília: MAPA, 2016. Disponível em: <http://www.agricultura.gov.br/febreaftosa>. Acessado em: 26 set. 2017.

JACOBS, R.M.; MESSICK, J.B.; VALLI V.E. Tumors of hemolymphatic system. In: MEUTEN, D.J. (Ed.). Tumors in Domestic Animals. Iowa: Iowa State Press, 2002. p.119198.

LEAL, P.V.; PUPIN, R.C.; SANTOS, A.C. et al. Estimativas de perdas econômicas causadas por reação granulomatosa local após uso de vacina oleosa contra febre aftosa em bovinos de Mato Grosso do Sul. Pesqui. Vet. Bras., v.34, p.738$742,2014$.

LIMA, D.C.P.; COSTA, A.S.; FERREIRA, M.D.S.; SOBRINHO, J.M.F. Febre Aftosa: ocorrência de nódulo pós-vacinal segundo via de aplicação da vacina. Pesqui. Agropecu., v.20, p.167-172, 2014.

MARQUES, A.L.A.; SIMOES, S.V.D.; MAIA, L.A. et al. Compressão medular em bovinos associada à vacinação contra febre aftosa. Ciênc. Rural, v.42, p.1851-1854, 2012.
MCALLISTER, M.M.; O'TOOLE D., GRIGGS K.J. Myositis, lameness, and paraparesis associated with use of an oil-adjuvant bacterin in beef cows. J. Am. Vet. Med. Assoc., v.207, p.936938, 1995.

O'TOOLE, D.; STEADMAN, M.; TORPY R.R. Myositis, lameness, and recumbency after use of water-in-oil adjuvanted vaccines in near-term beef cattle. J. Vet. Diagn. Invest., v.17, p.23-31, 2005.

O'TOOLE, D.; MCALLISTER, M.M.; GRIGGS, $\mathrm{K}$. Iatrogenic compressive lumbar myelopathy and radiculopathy in adult cattle following injection of an adjuvanted bacterin into loin muscle: histopathology and ultrastructure. J. Vet. Diagn. Invest., v.7, p.237-244, 1995.

PANZIERA, W.; BIANCHI, R.M.; GALIZA, G.J.N. et al. Aspectos epidemiológicos, clínicos e anatomopatológicos do linfoma em bovinos: 128 casos (1965-2013). Pesqui. Vet. Bras., v.34, p.856-864, 2014.

PANZIERA, W.; RISSI, D.R.; GALIZA, G. et al. Pathology in pratice: spinal cord compression due to vaccine granulomas in two calves. J. Am. Vet. Med. Assoc, v.249, p.483-485, 2016.

SHERMAN, D.M.; AMES T.B. Vertebral body abscesses in cattle: a review of five cases. J. Am. Vet. Med. Assoc., v.188, p.608-611, 1986.

UBIALI, D.G.; CRUZ, R.A.S.; LANA, M.V.C. et al. Spinal cord compression in cattle after the use of an oily vaccine. Pesqui. Vet. Bras., v.31, p.997-999, 2011. 